\title{
Research on College English Teaching Based on Inquiry-based Teaching Mode
}

\author{
Min Zhang and Ya Fang \\ School of Foreign Languages, Northwest University, Xi'an, Shaanxi, 710127, China \\ zyzmm@hotmail.com
}

Keywords: College English teaching, Inquiry-based teaching mode, Practice

\begin{abstract}
Key research universities in China studied how to conduct inquiry-based teaching research on senior grade professional course of engineering management. The teaching mode that is problem centered, research and experimental projects centered has been reformed. Trying to research the application in teaching has also achieved good results. We believe that the reform and practice of inquiry-based teaching methods and mode should not be confined to senior professional courses, but should run through the whole process of undergraduate education. Therefore, it is a worthwhile research and discussion of theory and practice as to explore whether it is possible to carry out inquiry-based teaching in College English teaching and build corresponding teaching mode.
\end{abstract}

\section{Introduction}

With the continuous infiltration of research and teaching, the inquiry-based teaching mode came into being. Each discipline actively regards the problem as a research in the learning process as first. It begins with medicine and engineering education, and then other disciplines also try to borrow. The study of teaching mode refers to the exploration on the problems of social investigation and teaching method. Based on the course content and student knowledge, teachers guide students to use knowledge and ability to creatively and independently identify problems, research and solve problems. This kind of teaching concept helps students accumulate knowledge and trains their ability of thinking. Under the guidance of the use case, a teaching plan is designed for teaching according to the inquiry teaching program. In the rapidly developing capitalist society, the relationship between people is becoming more and more indifferent. People's needs are not only reflected in terms of the material level, but also the psychological level. Therefore, psychology came into being and gained rapid development. The development of psychology has a profound influence not only on the cognition of teaching activities, but also in various aspects such as emotion, motivation and personality measurement.

This study starts with previous research results, and after consulting a certain number of relevant literature, aims at the theoretical deficiencies of previous studies. By combining the teaching experience of excellent English teachers, it sets up the inquiry-based teaching mode of College English, and also applies the mode to the experimental subjects. Before the mode is built, the students' interest in English learning, needs and preferences are investigated to determine the operability of the mode content. In the process of practice, teachers give feedback to the students' self-learning situation in time. After a series of group activities and the completion of the task, we compared the results before and after the experiment to verify whether the effect of mode implementation is obvious.

\section{The Construction of College English Inquiry-based Teaching Mode}

\section{Analysis of the necessity and feasibility of the construction of College English inquiry-based teaching mode}

In order to test the quality of College English teaching and students' learning level, the College English Test Band Four and Six were set up.in 1987, and has gone through 21 years of development. Nowadays, many job recruiters take CET-4 and CET-6 as rigid indicators, and students become more utilitarian in their English learning due to the tests [5]. With the development of society and 
the prosperity of economy, the international cooperation is becoming much closer. The English ability required by the society is not merely a requirement of CET- 4 or CET- 6 certificates [6]. The reform of the traditional college English teaching, that is, the reform of teaching mode, teaching materials and examination, is necessary. It is very important to optimize the current college English teaching mode, cultivate innovative consciousness, thinking and innovation ability of students, and improve their listening, speaking, reading and writing ability. A new teaching mode of College English that centers on inquiry and research for innovative education is very necessary to launch.

Through the investigation, we found that the students whose English are good have higher requirements in college English learning. The students whose scores are in the range 80-90 have sufficient mastery of the language, and take using the language as their main purpose. The statistics of 54 was significantly higher than the 36.4 we expected. Therefore, in the process of English teaching, we take English communication as the highest goal in college English education. Only $11.9 \%$ of the students were very willing to speak in English in the classroom, while $44.6 \%$ of the students were general, and $32.7 \%$ of the students only expressed their willingness. $53.1 \%$ of the students showed an indifferent attitude to the discussion of problems using English in the classroom, and $31.5 \%$ of the students liked it. $51.2 \%$ of the students did not know how to perform group tasks or assignments in English after class, and $33.1 \%$ of the students liked it. The above survey data fully demonstrate that the inquiry-based teaching mode for college English can be implemented.

\section{The connotation of College English inquiry-based teaching mode}

With the development of economy and the increasing trend of internationalization, the demand for English talents is increasing. Not only the "hardware" certification of CET-4 and CET-6 are needed, but the "software" embodiment of the ability of hands-on and oral communication is also required. The objectives of College English teaching change from cultivating students' English reading ability into cultivating students' comprehensive ability of English. Especially, the teaching modes of listening and speaking will be changed from classroom instruction into the combination of diversified classroom teaching and after class activities. The teaching evaluation system also changes from the single assessment to the combination of oral and written English abilities. The innovation of teaching ideas has given new breath to English teaching.

\section{The Analysis of the Practical Results of College English Inquiry-based Teaching Mode}

\section{Practice process}

The research object of this study is Class1 and Class 2 of 2015 Law major, and Class 1 and Class 2 of 2015 Chemistry major in a key comprehensive university. The practice time of College English inquiry-based teaching mode is from July 2016 to January 2017. The research methods adopted in this study are literature review and questionnaire. Before the construction of the mode, it investigates students' interest in English learning, needs and preferences. The purpose is to investigate whether the new mode is operable. From July 2016 to January 2017, it was mainly questionnaire design and survey of students' interest and preference in English learning. From February 2017 to April 2017, it was the data input, analysis of the questionnaire, and the writing of questionnaire survey report. Through the implementation of a semester's inquiry-based teaching mode of College English, from May to June 2017, we concentrated on the final exam results of four classes in the second semester and the third semester, and verified the effect of mode implementation.

\section{Practice method}

In order to better carry out English teaching, promote the reform and cultivate the students' habit of independent learning, a questionnaire survey is carried out on students of several classes. The purpose of this survey is to understand students' learning state, provide first-hand information for reform, grasp students' learning needs and attitudes, and make scientific teaching plans. The survey was launched in July 2016. 272 questionnaires were issued and 272 were received. The recovery rate was $100 \%$. The number of effective questionnaire is 260 and the effective rate was $95.59 \%$. The design of this questionnaire is mainly to investigate some situations of students' English learning. The basic information of students in the introductory section, such as gender, profession 
and so on, is to confirm whether the differences between gender and profession will cause certain influences to students' English learning.

\section{Practical Results}

\section{An analysis of the results of the study interest and preference of students}

For College English learning stage, $45.1 \%$ of the students in the Law Department are in score range of $60-70$, and $35.3 \%$ of them in 70-80. Among the students of Chemistry, $46.4 \%$ are in score range of $70-80$ and $32.1 \%$ of $60-70$. The achievement of this survey is slightly worse than that of Chemistry, and the academic achievement is slightly better than that of Chemistry. In the survey, the difference between college entrance examination of male and female is quite obvious, $42.5 \%$ of boys are in $90-110,24.3 \%$ are 120 points, while $44.3 \%$ of girls are in $110-120$, and $40.5 \%$ are more than 120 points.

\section{Performance analysis}

Through the implementation of a semester's inquiry-based teaching mode of College English, a series of English activities were launched. The scores of experimental subjects of Class 1 and Class 2 of Law major, and Class 1 and Class 2 of Chemistry increased significantly.

Table 1 Score statistics about Class 1 and 2 in Law and Chemistry respectively

\begin{tabular}{cllll}
\hline & $\begin{array}{l}\text { Law } \\
\text { Class 1 }\end{array}$ & $\begin{array}{l}\text { Law } \\
\text { Class 2 }\end{array}$ & $\begin{array}{l}\text { Chemistry } \\
\text { Class 1 }\end{array}$ & $\begin{array}{c}\text { Chemistry } \\
\text { Class 2 }\end{array}$ \\
\hline $\begin{array}{c}\text { Second } \\
\text { term average } \\
\begin{array}{c}\text { Third } \\
\text { term average }\end{array}\end{array}$ & 67.19 & 65.55 & 64.39 & 64.38 \\
\hline
\end{tabular}

From the calculation of the average of different terms in four classes, it is clear that every class has improved. The average division of Law major Class 1 changes from 67.19 to 70, Class 2 from 65. 55 to 67.58; Chemistry Class 1 from 64.39 to 66.82, and Chemistry Class 2 from 64.38 to 65.84 . After a semester of the inquiry-based English teaching mode, the students' achievements have basically improved.

Table 2 Score statistics about Class 1 and 2 in Law and Chemistry respectively

\begin{tabular}{ccccc}
\hline & Fail number & $60-69.5$ & $70-79.5$ & $\begin{array}{c}\text { More than } \\
80 \text { points }\end{array}$ \\
\hline $\begin{array}{c}\text { Second term average of } \\
\text { Law major Class 1 }\end{array}$ & 7 & 10 & 12 & 2 \\
$\quad \begin{array}{l}\text { Third term average of } \\
\text { Law major Class 1 }\end{array}$ & 6 & 3 & 11 & 6 \\
$\quad \begin{array}{l}\text { Second term average of } \\
\text { Law major Class 2 } \\
\text { Third term average of } \\
\text { Law major Class 2 }\end{array}$ & 6 & 15 & 8 & 2 \\
$\begin{array}{c}\text { Second term average of } \\
\text { Chemistry Class 1 }\end{array}$ & 10 & 11 & 10 & 3 \\
$\quad \begin{array}{l}\text { Third term average of } \\
\text { Chemistry Class 1 }\end{array}$ & 7 & 10 & 5 & 4 \\
$\begin{array}{c}\text { Second term average of } \\
\text { Chemistry Class 2 } \\
\text { Third term average of }\end{array}$ & 8 & 8 & 12 & 3 \\
Chemistry Class 2 & 8 & 13 & 8 & 1 \\
\hline
\end{tabular}

The evaluation of the effectiveness of English inquiry-based teaching mode is based on the combination of process assessment and ultimate assessment, oral test and written examination, 
teacher evaluation and student self-assessment, and mutual evaluation among students. Student self-assessment is mainly reflected in the evaluation of their tasks when accomplishing group tasks. Student's mutual evaluation is reflected in the overall evaluation of students' final effect on group tasks and the evaluation of each member's contribution. As long as the members of the group are actively involved, everyone will have an optimistic harvest.

\section{Summary}

In teaching methods, according to the introduction of cultural knowledge, using the input-output theory of psycholinguistics, and introducing advanced teaching methods of other disciplines, inquiry-based teaching and case teaching methods make good achievements in teaching. The opening of the second classroom has created a cultural atmosphere for English learning for students, which enables students to develop their language abilities, thinking abilities, intercultural communication and cooperation abilities under the influence of the second classroom. In short, the form is different, but the purpose is clear, that is, students experience the fun of learning, reapply it, and take part in the full participation as the purpose of language learning is to communicate.

\section{References}

[1] Crawford, B. A., Learning to teach science as inquiry in the rough and tumble of practice. Journal of Research in Science Teaching, 2007, 44 (4), 613-642.

[2] Hayden, H. E.; Chiu, M. M., Reflective Teaching via a Problem Exploration--Teaching Adaptations--Resolution Cycle: A Mixed Methods Study of Preservice Teachers' Reflective Notes. Journal of Mixed Methods Research, 2015, 9 (2), 133-153.

[3] Hayes, M. T., Elementary Preservice Teachers' Struggles to Define Inquiry-Based Science Teaching. Journal of Science Teacher Education, 2002, 13 (2), 147-165.

[4] Houle, M. E.; Barnett, G. M., Students' Conceptions of Sound Waves Resulting from the Enactment of a New Technology-Enhanced Inquiry-Based Curriculum on Urban Bird Communication. Journal of Science Education \& Technology, 2008, 17 (3), 242-251.

[5] Marzano, R. J., Using Action Research and Local Models of Instruction to Enhance Teaching. Journal of Personnel Evaluation in Education, 2007, 20 (3-4), 117-128.

[6] Olitsky, S., Facilitating Changes in College Teaching Practices: Instructional Reform, Identity Conflict and Professional Community in a K-20 Partnership. Research in Science Education, 2015, 45 (4), 625-646. 